\title{
BILATERAL COOPERATION BETWEEN THE GOVERNMENT OF INDONESIA MALAYSIA ON MANAGEMENT BORDER TERRITORY
}

\author{
Jawahir Thontowi \\ Faculty of Law, Islamic University of Indonesia
}

This study reveals that bilateral cooperation between the government of Indonesia-Malaysia began to continue since 1960. It was untul 1974, two Governments signed MoU and followed to by 25 join diplomacy meetings in persuing border problem. In practice however, it is found it difficult for Indonesian government to progress people development in border area. Not only because the Indonesian and Malaysian negotiation diplomacy are less effective to prevent and control border area, but rather because too many factors are faced by central and local governments of Indonesian, to issue a special regulation which is internally relevant to solve the problem of borderarea.

\section{Keywords:}

International Law, Border Area, Cooperation, Total Diplomacy and.Local Diplomacy, tangible and untangible factors.

\section{Introduction}

erritory is one of the main requirements of establishing a state (Montevideo Convention 1933) among other requirement such as a population, government and the ability to conduct foreign relations. If a country stands without clear boundaries they are generally 'difficult to unite a legitimate power of government. Palestine until today has not gained full status at the United Nations (observer) because its borders remains in the status quo (currently searching for a peaceful resolution). It is therefore, attention towards Palestine must still be raised considering the occupation by lsrael.

Indonesians, live in a country with complex territorial border problems. On the one hand, Indonesia is a vast archipelago state (Negara Kepulauan), its borders are bounded by land, sea and air which is unified under Wawasan Nusantara which means insight into the archipelago. On the other hand, the forces of globalization, State borders physically shifts into boundaries in cyber-space as if there are no longer any boundaries or borderles (W. Michael Reisman, 1999). Consequently, the challenges in the society and government of Indonesia require a comprehensive understanding ón border issues.

Since the enactment of the Law Number 43 Year 2008 on the territory of the State, seems increasingly clear that the central government needs the priorities management of land boundaries for the region. At least four provinces, Papua (Irian Jaya) with Papua New Guinea, NTT (Attambua) with East Timor (The President SBY with President East Timor discussed the unresolved borders disputes which is in Noel Besi Citranus Kabupaten Kupang (KOMPAS, March 23, 2011), East Kalimantan and West Kalimantan with Malaysia. The government administrations that are situated on the border region consist of 16 districts/municipalities in 66 sub-diștricts which spans no fewer than 10 provinces, 33 districts and cities, and 131 sub-districts (Gamawan Fauzi,. KOMPAS, December 14, 2011). This situation encouraged the central government, especially President of Indonesia to issue a policy. The Presidential Decree Number 12 Year 2010 on the establishment of the National Border Management Agency (BNPP), gives mandate in order to prioritize the management of land boundaries in Indonesia. In relations to that, the Local Legislative Body (DPD) assess that the management of border requires a grand strategy (KOMPAS, March 17,2011)

The new policy is demanding to present several reason. Firstly, such a situation can easily ignite conflict between the two countries in border areas. More over, if the imaginary boundaries that are substantive (determination of coordinates) ignores attachment in maps which are based on the International Convention, the legal uncertainty of Indonesia and Malaysia border region become most vulnerable. 
Secondly, the absence of bilateral treaties was fundamental challenge to be aware by both countries that MoU 1974 was not good enough to be bound effectively. Thirdly, if the model of foreign relations and cooperation among the countries that border only based on the principle of absolute sovereignty, there will be problems being faced by the people living in the border region. That non-physical challenge is made up of political policies which are translated into legal instruments related to the role of central and local governments, law enforcement officials, socio-cultural and economic conditions. In order to get e better understanding, this article aims to address certain border issues. One is dealt with the question how international law defines border areas proceeded by introducing rights and obligation of the states. An other what challenges would indonesian government be faced to respond the Indonesian people in border areas? Thirdly, is how would the Indonesian government and Malaysian government deal to overcome the problem of the border?

\section{Determining Boundaries The Perspective International Law}

The sovereign territory of a state in international law means the rights and obligations to control the region as a whole (territorial integrity). In determining the boundaries, there is theoretical framework on take into the application of the right and obligations account.

\section{The Rights and Obligations of the Integral Sovereign State}

Determining the rights of sovereignty can be described as follows: (1) The right to enforce sovereignty of the legislative (makes the laws), executive (government administration) and judicial (and executing power of the judiciary); (2) The right to enforce exclusive sovereignty for violations and crimes committed by citizens of other countries in the region. For example, making arrests, the investigation and legal proceedings in a fair and independent court; (3) The right to not allow its territory empty of activity of state sovereignty (ineffective occupation). For example, build a lighthouse, clear boundaries, as well as the implementation of community activities as citizens to emphasize that the area is not empty. Sipadan-Ligitan case won by the International Court of Justice, as well as proving the Indonesian government documents are weak, as well as evidence of a disregard for the principle of effective occupation. (JG. Starke, 1983; and also Malcolm Shaw; 1986).

An understanding of those rights, of course, it is only possible cooperation can occur after the two countries are mutually recognized each other. Enforcement of international obligations is very important to note because each UN member state has the obligation to comply with and be bound: (1) Uphold peace and world order with the obligation to resolve all disputes peacefully and avoid the use of violence; (2) Each State shall respect and uphold the principle of equality between sovereign states (equality before sovereign countries) therefore it is prohibited for each State to intervene (Non-Intervention) on affairs domestic and foreign affairs of neighboring countries or other friendly nations; (3) No action on the sovereignty of another country as a state police makes arrests perpetrators for crimes in other countries. United States of America Police capture suspected terrorists in Indonesia without the knowledge of a indonesia Police is a violation of sovereignty; (4) Not allow the citizens committing crimes of sovereignty/treason. In case of Dr. Azahari and Nordin M. Top were regarded as pugitive people from Malaysia who able to inspire Indonesian terrorist. In this context, however the Malayasian government fail to take legal responbility, because they did not return to their homeland until they were shot dead in Indonesia: As a good will, Indonesian government sent funeral Dr. Azahari and Nordin M. Top back to their homeland, Malaysia.

\section{Determination State Boundaries Region}

In determining the boundaries, there are several legal theories adopted by international law. The modes of acquisition of territory is as followed. The first, the concept of terra nullius, cession (peaceful submission), (conquest violent of millitary occupation) (Sutisna et.al., 2010). In more technical, the determination of boundaries is the allocation (the early stages of the division line between the parties), delimitation (boundary determination by providing natural or artificial signs), demarcation (affirmation of the border, a border region through an agreement and the provision of signs as outlined in a MoU or Bilateral . 
agreements. Established of a Joint Border Committee with the aim for cooperation of management and supervision associated with the borders between countries (Ludiro, 2010) . Government of lindonesia and Malaysia has a MoU on Joint Border Committee which of course is still common, for example,

Second, Uti Posidetis, determining the boundary territory of a state based on the inheritance of previous government power. For example, the Indonesian government determines its boundary from Sabang to Merouke based on the previous Dutch rule, and based on the maps attached to the bilateral agreement between the Dutch with United Kingdom. The coordinates from maps that are attached to Bilateral Agreement between states governments can become the main source of law to confirm the boundaries of a country.

Third, demarcation, an agreement confirmation- of physical boundaries (the natural and artificial boundaries) and imaginary boundary by the two neighboring countries, with calculating and determining the fix and permanent coordinates. The boundary agreement is formulated into an agreement between the two countries and that must be followed up with the ratification-by the legislative / judicial of each respective country. Theoretically the judiciary of the two countries, namely Indonesia and Malaysia as the neighboring countries having no other choice but to preserve good relations, especially relates with efforts to conduct joint monitoring of populations crossing borders.

The fourth, bordes management which is to be done by making an agreement both countries tojoin contract and management border and prevent border.conflict from happening. It generally functions to perform public services, population registration, physical and spiritual development which cover aspects of politics, economics, defence and security, and other infrastructure should built (Sutisna, 2006). This program should actually be conducted by indonesian government.

\section{Indonesia Challenge On The Boundary Territories}

There are two challenges that need special attention from the government of Indonesia. The first is related to the physical challenges of the border region (Tangible Factors) and the challenge of non-physical borders (Intangible Factors).

\section{Physical Factors of Border Region(Tangible Factor)}

Central government's policy towards the physical boundaries, especially the mainland has become a priority. Four provinces are included, Papua (Irian Jaya) and Papua New Guinea, NTT (Attambua) with East Timor, East Kalimantan and West Kalimantan with Malaysia. The district administration is situated on the border region which consist of 16 districts/municipalities in 66 sub-districts. No fewer than 10 provinces, 33 districts and cities, and 131 sub-districts. The President need a particular attention. To respond this policy, BNPP, to issue a policy, namely Presidential Decree Number 12 Year 2010 on the establishment of the National Border Management Agency (BNPP). By estabhlising it will immediatly help the problem of border between Indonesia, Malaysia, East Kalimantan and West Kalimantan and it is currently seen as a highly critical condition need to be addressed.

\section{a. The Long and Vast Border Region}

West Kalimantan is on the same island with a town in Sarawak, it is located in the front porch of two countries. The border region is considered having the most vulinerable position of threats to defense and state security. Along the $1.200 \mathrm{~km}$ border, are located in two provinces of Indonesia namely West Kalimantan and East Kalimantan where a framed border is very important for Indonesia. Mayor General. Geerhan Lantara, Military Command Headquarters XIl in Tanjungpura, Pontianak confirmed that the data in the border areas of West Kalimantan Province is based on the facts as follows: It has a length of $966 \mathrm{~km}$ and a width of not less than 5785 markers, with a covering 5 districts, 15 sub-districts and 98 villages

The long border length between Indonesia and Malaysia and the weakness of the Indonesia government to conduct monitoring is often the root of the problems. The alleged occurrence of the shift markers in the Camar Bulan in Tanjung Datu is a sensitive case which will probably reoccur. Previously, Malaysia claimed Ambalat in East Kalimantan region has disrupt the good relations between Indonesia and Malaysia. Indonesia community protested against Malaysia government was invitable consequence 
mainly because confrontational demonstrations that occurred in several large cities in Indonesia, especially in Jakarta (Jawahir Thontowi, GATRA, 2007). Limited information and less powers of the defenses forces to contribute on land and sea for Indonesian appears to have resulted in the emergence of such imbalances.

The solutions proposed by the central governmentneed strong support. Central government policies are strengthened when the President formed, the National Border Management Agency (BNPP) which is currently still looking for inputs to formulate the Grand Design (KOMPAS, November 11, 2010). West Kalimantan is relevant as a pilot project in the Border Region Acceleration Development Program. In line with government policy, Djoko Siyanto, Minister Coordinator of Politics, Law and Security, stated that the draft program for prioritizing development in the border region has been submitted to the district and provincial levels. Ministries and other State institutions will support the program (Reuters, February 1, 2011). This view should be followed up by the Minister of Foreign Affairs of Indonesia to become the specific agenda of talks involving the Minister of the interior. The Minister Coordinator of Politic, Law and Security, stated, there is a tendency that more policies will lead to a comprehensive model of diplomacy. A model of cooperation where the Ministry of Foreign Affairs is not only the sole back bone for relationship out of the country, but aiso the important roles of all others institutions of the government. The involvement of the central government to make a better relations by improving the status of MoU 1974, become bilateral treaties enforce to be bound effectively.

\section{b. Marginalized Population}

The population living around the border region is approximately 176,000 inhabitants. Most of the people living there are socially and economically marginalized. When compared with neighboring countries such as Malaysia, Sarawak, for example, the public image of indonesia in the border region is cause for serious concern. They generally work in agriculture and plantations, or limited to small scale trade. Several opportunities work in the government sector at the local level but usually these positions are usually filled by migrants from the outside area.

Influenced by a past history of rebellion, especially in 1966, when the Communist Party Massacre, has impacted negatively on the lives of people in the border region. The situation sparked the central government policy in the New Order government era against the people in the border region. The central government has always applied defense and security approaches to the people in the border regions. Moreover, in 1991, some areas of the Sambas district, roads are constructed to ease the movement of military personnel. Eventhough buildings built the BDC (Border Development Border) project with the small streets heading to the international-border crossing region in Sajingan Besar subdistrict has been ignored by central government.

\section{c. Limited Public Service Facilities}

In general, public service facilities, government offices, educational facilities, health facilities such as hospital and health centers are limited. It is difficult to improve these public facilities. The facilities and infrastructure means such as adequate roads and communication devices are still limited. Even if there is infrastructure available the quality level of human resource is very limited. There is a hospital but nol hardly any doctors. There are educational facilities (elementary, middle and high school buildings) but teachers are very limited in numbers. Not surprisingly that people in the border region fulfill their basic needs to neighboring countries such as Malaysia. Indonesians seeking work in Malaysia can be easily understood. However, it would be dangerous if the issue of Indonesian people who become laskar wathoniyah (if it occurs), in Malaysia and / or become workers in the sectors of defense and security. Of course it is not easy to blame the neighboring country, but precisely because of the demands of the stomach, poverty eradication is the main priority. Nationalism without economic security, justice for Indonesian citizen at the border, they will not choose to die, but prefer to migrated and work in Malaysia (Jawahir Thontowi and SaruArifin, 2008).

This the reason why Gamawan Fauzi confirmed that the border region should not be the kitchen or the back yard of the house, but it should be a beautiful front porch. BNPP will be more helpful to a function 
to do the coordination with all parties related (Ministry of Foreign Affairs, Coordinator Ministry Politic Law and security, Minister-Economic Affairs, and Ministry of Regional Development of Disadvantaged and Marginalized). The management of border, will lead the people become more prosperous, wealthy and feel a sense of justice. The role for BNPP is currently to improve a better condition for the people in border area is seen optimistic. One aspect, the Ministry of Forestry enacted a decision which is designed to make a strategic plan to manage forest of border area between Indonesian and Malaysia are important support (Minister Decision No: 55/Menhut-VII/2004), Concerning managing forest of border area between Indonesia and Malaysia)

The opportunity is open because the State Ministry enacted a decision which to make national strategic fo isolated development, which is designer isolated regional development (Ministry Decision No:001/Kep/M-pdt//2005). The support is also given by the Ministry of Intsior Affairs by enacting two important policies. They are standarization of infrastructure and border crosses services for within countries. Another policy is dealt with a guidance to forming a body of border management region. (See Minister Decisions No. 18/Year 2007, No. 31 Year 2010, and No. 2 Year 2010 (Organization and Operational Border for Permanent Secretary of Regional Border Management). Another important attention is the local authorities in the border region Indonesia need to be given the authority or the ability to perform basic and limited partnership model dispute resolution.

\section{Non Physical Challenge of the Border Region (Untangible Factors)}

The non-physical challenge for Indonesia to the border region is the rise of offenses, violations and crimes in the border region. Both, West Kalimantan and East Kalimantan to Sarawak considered most vulnerable to the violation of immigration documents, threats and the danger of cross-border crime (transnational organized crime), illegal logging and human trafficking.

\section{a. Violations of Immigration and Civil Cases}

Some cases that often arise are the question of immigration and civil cases. In some places, like in Sajingan Besar, Sambas district in the province of West Kalimantan often occurs is border crossing only use PAS Lintas Batas which is permit to across the border. Unfortunately also used the people who are living outside the border region can also use it. In reality, however, sometimes they do it, even though,they do not have rights because they are living outside the border region. The buying and selling sugar using a $P$ asi (riding motorcycle) which is motor carrier for transporting sugar is transported from the Biawak (Malaysia to Sambas). There is an absence of a standard mechanism of immigration and customs. The officers in Malindo post security control, are tolerance to pass many Pasi, besides motor that carry $100 \mathrm{~kg}$ to $150 \mathrm{~kg}$. This could be understood because the price of sugar is cheaper and if sold can get bigger profit.

Non-physical challenge is the importance of empowering the role of local government, both at the district level, sub-district and village administration. This arises as a consequence of the reality of people who often communicate on the basis of traditional reasons. Including, in which the importance of their understanding of conflict resolution models that are beyond the official completion of the external affairs at the Ministry of Foreign Affairs. Cases of legal conflict between the two different citizens in matters of marriage, inheritance of land conflicts and violations of traffic without a formal permit (Border Cross Pass) they can generally resolve them peacefully at district government level between the respective governments in the border region.

\section{b. Illegal Logging}

As for the ongoing cross-border crime and comprehensive supervision is needed to overcome the difficulties of Transnational Crime. Cases of illegal logging, both in West and East Kalimantan are almost equally rampant as a cross-border crime. The difference character of the crime on illegal logging in East Kalimantan uses the sea, while in West Kalimantan on the mainland. Not easy to control the increasing number of illegal logging crimes (2001 - 2002), still occurs in East Kalimantan to Sabah, in West Kalimantan to Sarawak. Research reports in Sarawak states that an average of 150 ships per month with 60 trucks. Meanwhile, in Entikong, Sanggau to Tebedu, Sarawak 75 trucks per day. For the Government of 
Indonesia and security personnel, the situation is very alarming, the imbalance between security forces and length of border areas is uneven. For example, there are 50 paths that connect 55 villages in West Kalimantan with 32 villages in Sarawak. While it is agreed by both countries only covers 6 villages in West Kalimantan and the 10 Villages in Sarawak, the two countries fail to establish legal enforcement respectively, it is not impossible to triger a tension relations.

c. Human Trafficking and Migrant Workers

The crime of buying and selling humans (human trafficking), smuggling of goods and services or the unauthorized trading (smuggling and illegal trading), generally occurs in two places, namely Entikong Sanggau district, and Sajingan Besar in Sambas district. For example, the smuggling of illegal migrants passing Entikong an estimate of 600 people per day ("Entikong After 64 years Rl", http //news.okezone.com/read/2009/, retrieved Wednesday, August 19, 2009. 09:43 pm). Neighboring. countries who have claims to the territory of the Republic of Indonesia, both in the dispute will be an area prone to regional stability, both in terms of bilateral relations, multilateral or from activities of cross-border crime.

The position of West Kalimantan is seen as a gateway to other countries, because it can be the source of suppliers as well as transit areas in the delivery of Indonesian Workers (TKI) from other regions in Indonesia. The trend of West Kalimantan, especially since the opening Entikong Tebedu in Sarawak and West Kalimantan has become a major labor route into Malaysia is now wide open. In 2003, from August to September was recorded around 2336 workers from nine (9) areas in .Indonesia namely Semarang, Yogyakarta, Surabaya, Jakarta, West and East Nusa Tenggara, Jambi, Sulawesi and West Java. Of the nine regions of origin, then the three highest Surabaya area.(658), West Nusa Tenggara (484), and Yogyakarta (470). (Wahyuni đKartikasari. 2005:44). Data relating to cross border migrants, until now still suggest the number has a tendency to increase.

\section{Role of Governments Diplomacy}

As a friendly neighboring country, both countries have committed to comply with international law, whether the provisions of the Vienna Law on Diplomatic and other international agreements. It is about 84 negotiation between Indonesian and Malaysia government. Which include in matters a politics, economics, trading, education, extradition, and migrant workers. Not less than 26 meeting border issues join diplomacy meeting were formed by both Indonesian and Malaysian government since 1960 to 2010. Memorandum of Understanding was signed 1974 by both countries relating to delimitation and demorcation in border area of West and East Kalimantan and Serawak Malaysia. In Practice, however, this diplomatic effort do not change positively the people of border area, in the province or state do not frequently overcome local issues is due to a far distance from central government is a major reason to set aside border problem.

\section{Diplomacy at Central Govenment Level}

As a neighboring country, it would be naive if the government of Indonesia and Malaysia do not recognize the existence of a relationship of mutual dependence. Not only, economic and political interests of ' safety, but also from the aspect of culture. Indeed, touching on aspects of culture seem to get less attention, so that various issues of conflict are so eașily exploited by the mass media. For example Sobar Sutisna, suggest that a better solution for managing border issue, is necessary to change the view of central government toward border area, and the autonomy and it's coordinations between central and local government to make relevant programs. It is believe or not, there is a controversy between the two countries.(Sabar Sutisna, 2012). As a result of lack of awareness of both countries a view minor cases, that behind it all there is a driven global "grand design" to which certainly disrupt a harmonius relations between Indonesia - Malaysia.

In spite of the fact that lot of weakness are faced, there is on the main point, the high willingness of both countries have dependence relationships so it is adequate to improve relations outside of formal channels of politic, economy, law and governance. This becomes very importance not only because the issue of transnational crime, such as smuggling, illegal logging, human trafficking, children and women, as well as 
illegal arms sales are involved. The problem of managing people in the border region, which sometimes produce a small pebble that could disturb the two countries relations. Indo Dwi Yono (2007) and Yayan Muhammad Yani (2008) suggest in a similar view, Indonesia government need to take a priority to develop security approach in border area, but it also to overcome disparities of social and economic condition between people of Indonesia and Malaysia where they live in border area. In addition to that, Indonesian government policy will never be effective to change the people without understanding local cultural values. (JawahirThontowi, 2008). Join cooperation between Indonesia and Malaysian government on border area is therefore required not only to strengthen security and defence approaches, but social economics and cultures values of local people should also take into consideration.

The need of total diplomacy should simultaniously performed by mobilizing the strengths of all stakeholders, government institutions, diplomatic representatives, security and defense, education institutions and residents of central and local levels.

\section{Local Government Diplomacy}

Given the fact the border is far from the center of government, then attempt to establish the foreign cooperation between Indonesia and Malaysia is impossible without changing mindset of the people. Foreign partnership model is currently being the center of foreign affairs is good, but not good enough when people are marginalized in the border region can gradually be extended. Socio-economic disparities and a culture that too sharply exist between the two populations living in border Sajingan, Entikong, Tebedu, in West Kalimantan and Sabah, Sarawak in Malaysia, will often cause problems for both countries.

In this paper, local diplomacy interpreted as an effort to empower the role of Provincial and Local Government Districts build in the material, infrastructure, and immaterial for people who specially live in border areas of West Kalimantan and East Kalimantan. The inclusion of Sabah and Sarawak logal government is also a vital role to represent local diplomacy from Malaysian side, resolve cases of abuse and transnational crime.

Several cases are involved that local diplomacy operate between local government at Sajingan Besar, Sambas district. This is a kind of opportunities fot both. Indonesian and Malaysian government to strengthen cooperations. Firstly, the approach of kinship is important in local diplomacy for the people living in border areas. This case generally occurs when a very well-established kinship ties, both in Sajingan Besar, Sambas District with villagers in the district of Sambas. Borders in West Kalimantan generally have the same tribe and religion. It is very important approach kindship involved in local diplomacy given the role of informal leader and adat and religion play an important role in the lives of rural villagers in the border region. Different marriage naturaliti practice often occure between Indonesian women and Malaysian men. This practice is an interesting case, because neither they follow Indonesian Marriege act No. 1 Year 1974, Not do they come to register their marriege in Civil Register Office. In customs practice, however, the head of adat (customary institution) are able to perform marrieage ceremony without observing the Indonesian Marreiage Act. Even though the marriege practice is illegally recognized, the people in Sajingan Besar view it as legitimate.

Secondly, illegal border crosser sometime become sensitive cases within national diplomatic offices when the dispute is not settled by local district government. For example, seven Indonesia Officers|from Jakarta crossed Pas Malindo September 2007 without legal document and ignoring a guide person from subdistrict officers. During travelled in Biawak Village, Malaysian policer arrested them and detained them in jail for a few weeks. Initially, the case brought to court in Serawak. Indonesian Officers were found guilty not being seen legal imigration documents. Judges of Malaysian Court, give seven offenders a fine more high thousand ringgit. Indonesian central government tried to negotiable and rejected to pay a fine. For that solution, Indonesians offenders were eventually released from detention, since local government of Sambas, Kapolres, Imigration Officers, Bupati, Assistance tackled their cases by making direct visit to local government in Lundu subdistrict. Seven offenders could finally return to Jakarta without fine. The subdistrict governmentas th sub ordination serves to coordinate not only in terms of providing public services and to basic needs, but also it will be in the frontline of settlement administration, including the completion of conflict between the different communities citizenship. The less public services are provided can gradually improved if the local 
government is permitted to issue a special policy in order to enhance the people in border area of both socially and economically.

Indonesians citizens are more dependent in Lundu subdistrict, in respect to basic needs and medical services. Usually, the people from Sajingan prefer to come and go to Lundu in Serawak, to buy sugar and vegetable oil, due to chiep price. Sometime, the people visit Lundu to request a medical assistance, which it take into account for emergency reason, or because Sambas hospital is too far distance to reach. In addressing the main problems of the population in the border region need to coordinate with relevant ministries. The presence of BNPP and the formation of Regional Border Management Agency will be more effective to develop is due the role support of Minister of International Affarir and also the Ministery of Forestry on the people of border areas.

The implications of this local diplomacy, Indonesian government can push for the government especially the Ministry of Interior, Ministry of Foreign Affairs, Coordination Minister of Political, Law and Security to coordinate the diplomatic part of the authority in the border region can be done by the Mayor, with clear legal protection, either through the instrument of Local Government Law, Foreign Relations Law. And other legal instruments at material levels.

\section{Conclusions}

Based on previous discussion some conclusion would contiuedly be drawn as follows. First, regulation and management of border areas may not be made without reference to the theoretical and juridical framework of international law by considering the conditions of each neighboring country. Several methods such as allocation, delimitation, demarcation and cooperation with supervision (Joint Border Committee), including the principle of uti posidetis, the use of maps and appendices MoU inherited colonial government (the UK to Malaysia in 1891, 1915, 1928 (general boundaries) and the Netherlands would help both countries to overcome problem of border area

Second, the lack of political will from the central government, as formulated in the Law Number 43 Year 2008, and Presidential Decree Number 12 Year 2010, are legal instrument that give the legitimacy and accountable to the President and its cabinets. They are Ministry of Interior and Foreign Affairs, and Coordinator Minister Politic, Law and Security, confirms the integrity of the integrated border region by coordinating to the sovereignty internal affair. In relation to the policy that people living in border areas, should not only be changed from the approach to security and defense (defense and security approaches), but rather should be directed to the development of the welfare and prosperity.

Third, the existence of boundaries on land and sea that often raises tension between the government and people of Indonesia with neighboring countries are required to solve two major problems. The challenge of the physical (tangible factors) and non-physical (non-tangible factors) have been exhibited significantly affect the incidence of inequality among marginalized communities in the border region. It particularly take in West Kalimantan with a prosperous and affluent people living in the area Malaysia border.

Fourth, the inequality caused by the people of Indonesia who are living in the border region, prompting the emergence of an act of violations in aspects of immigration and civil matters, and transnational crime, such as illegal logging, smuggling and buying and selling of human to prostitution (Human Trafficking) masquerading as workers. This will often cause interference indonesia partnership, when the two countries do not start to improve comprehensive cooperation, good cooperation in the context of diplomacy and cultural approaches. An attempt of local diplomacy in this paper is perhap one solution that needs take into consideration by central government.

Fifth, The development of border management policy of Indonesia and Malaysia, more specifically, the bilateral cooperation not only BNPP can be a central coordinating border management including enforcement of transnational crimes, but also no less important authority the central government, particularly Minister of Interior, Ministry Foreign Affairs and local governments to conduct local diplomacy in West Kalimantan and East Kalimantan in an effort to accelerate a range of public service that not only their basic needs, but the immigration and settlement. of civil disputes can be resolved by local governments through a persuasive approach to cultural and othermeans. 


\section{REFERENCE}

Arifin, Saru (2009). "Pelaksanaan asas Uti Posidetis dalam penentuan titik patok perbatasan darat Indonesian dengan Malaysia", Jurnal Hukum, Yogyakarta, Vol 16 No. 2.

Gamawan Fauzi, KOMPAS, December 14, 2011

Hadi, Suprayoga,. "Program Pembangunan Kawasan Perbatasan", http://bulletin.penataanruang.net (diakses tanggal 2April 2012).

Huda, Ni'matul.(2010). Problematika Pembatalan Peraturan Daerah. Yogyakarta: FH UII Press.

Kartikasari, Wahyuni (2005). Trafficking di Wilayah Perbatasan Kalimantan Barat-Sarawak, Tesis Magister Ilmu Politik Program Pascasarjana, Universtas Gadjah Mada, Yogyakarta.

Madu, Ludiro (2010). Mengelola Perbatasan Indonesia di Dunia Tanpa Batas. Yogyakkarta: Graha Ilmu.

Prescott, Victor (2008) International Frontiers and Boundaries: Law, Politics and Geography. Leiden: Martinus NIJHOFF Publishers.

Shaw, Malcolm (1986) Title to Territory in Africa. Oxford: Clarendon Press.

Starke, JG. (1983) An Introduction of Internatioan/ Law. Sydeny: Butterworth.

Sutisna, Sobar et.al. (2010) Boundary Making Theory dan Pengelolaan Perbatasan di Indonesia, dalam Mengelola Perbatasan Indonesia di Dunia Tanpa Batas: Isu, Permasalahan, dan Pilihan Kebijakan. Yogyakarta: Graha Ilmu.

Sutisna, Sobar (2006) Pandang Wilayah Perbatasan:-Aspek Permasalahan Batas Maritim Indonesia, Pusat Pemetaan Batas Wilayah, BAKOSURTANAL

Thontowi, Jawahir and Saru Arifin (2008) Pengembangan Masyarakat di Pusat Pengembangan Wilayah Perbatasan, Kajlan Pemerintah Daerah Sambas dan CLDS FHUII.

Thontowi, Jawahir (2009) Kewenangan Daerah Dalam Melaksanakan Hubungan Luar Negeri, Jurnal Hukum lus Quia Isutium, Yogyakarta, Vol 16. No.2

Thontowi, Jawahir (2009) Penegakan Hukum diEra Presiden SBY. Yogyakarta: Leutika.

Reisman, W. Michael (1999) The Library of Essays in International Law Jurisdiction in International Law.

KOMPAS, March 23, 2011

KOMPAS, March 17, 2011

Reuters, February 1, 2011

Entikong After 64 years Rl. Http // news.okezone.com/read/2009/. Retrieved Wednesday, August 19, 2009. 09:43 pm 